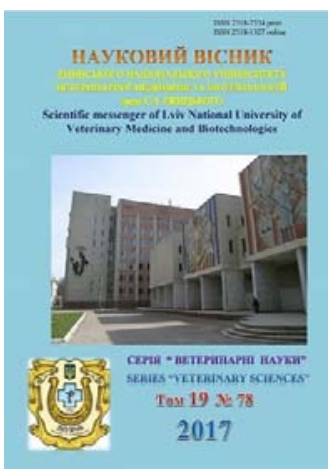

Науковий вісник Львівського національного університету ветеринарної медицини та біотехнологій імені С.З. Гжицького

Scientific Messenger of Lviv National University of Veterinary Medicine and Biotechnologies

doi:10.15421/nvlvet7831

ISSN 2518-7554 print

ISSN 2518-1327 online

$\underline{\text { http://nvlvet.com.ua/ }}$

УДК 619:616.98-091:636.7

\title{
Гістологічні зміни в собак за коронавірусної інфекції
}

\author{
В.В. Лісова, О. Дубіненко \\ lisovav@ukr.net

\begin{abstract}
Національний університет біоресурсів і природокористування Украӥни,
\end{abstract} \\ вул. Героїв Оборони, 11, м. Київ, 03041, Украӥна
}

\begin{abstract}
У статті наведено результати вивчення гістологічних змін в органах і тканинах собак за коронавірусної інфекції. Проведено гістологічне дослідження патологічного матеріалу, відібраного від трупів $(n=5)$ собак різних порід і статей віком від 2-х до 6-ти місячів, щ⿻о загинули з діарейним синдромом. Присутність коронавіруса, без інших асоціантів, в даних випадках була раніме підтверджена у полімеразній ланцюговій реакиії при аналізі зразків фекалій. Виготовлені гістологічні зрізи фарбували гематоксиліном й еозином за стандартними прописами. Загальну гістологічну будову і мікроструктурні зміни в гістологічних препаратах вивчали під світловим мікроскопом.

Гістологічним дослідженням були підтверджені й доповнені патологоанатомічні діагнози, встановлені після розтинів трупів загиблих тварин. Найбільш виразні пошкодження й типові зміни в усіх загиблих собак зафіксовані нами в тонкому відділі кишечнику (в порожній і клубовій кишках) і ретіонарних до нього лімфатичних вузлах, а також в селезінці. Показано, що морфологічними проявами коронавірусної інфекиї в загиблих собак на мікроскопічному рівні є такі ознаки: наявність ексудативного запалення в тонкому відділі кишечнику у вигляді серозно-фібринозного єюно-ілеїту; гіперплазія одиноких $i$ скупчених лімфоїдних вузликів слизової оболонки тонкого відділу кишечнику; гіперплазія і серозно-геморагічний лімфаденіт мезентеріальних лімфатичних вузлів; фокуси геморагій і геморагічні інфаркти в паренхімі селезінки; гіперплазія лімфоїдних вузликів селезінки; фокуси геморагій в серозній оболонці тонкого відділу кишечника. Також неспецифічними, але постійними морфологічними ознаками, які виникали внаслідок порушення кровообігу і серцевої недостатності, були: пасивна венозна гіперемія печінки і нирок; дистрофічні процеси в паренхімі печінки й нирок. Отже, під час коронавірусної інфекиії розвиваються місцеві й загальні імунологічні процеси. Тому додатковими діагностичними маркерами виступають гіперпластичні й запальні зміни в ретіонарних до місиь репродукиії віруса лімфоїдних органах.

Ключові слова: собаки, коронавірусна інфекиія, гістологічні зміни, серозно-фібринозний єюно-ілеїт, геморагії, гіперплазія, лімфоїдні вузлики, серозно-геморагічний лімфаденіт.
\end{abstract}

\section{Гистологические изменения у собак при коронавирусной инфекции}

\author{
В.В., Лисовая, Е. Дубиненко \\ lisovav@ukr.net
}

Наџиональный университет биоресурсов и природопользования Украины, ул. Героев Обороны, 11, г. Киев, 03041, Украина

В статье представлены результаты изучения гистологических изменений в органах и тканях собак при коронавирусной инфекиии. Проведено гистологическое исследование патологического материала, отобранного от трупов $(n=5)$ собак разных пород и пола в возрасте от 2-х до 6-ти месячев, погибших с диарейным синдромом. Присутствие коронавируса, без других ассоциантов, в данных случаях было ранее подтверждено в полимеразной цепной реакции при анализе образиов фекалий. Приготовленные гистологические срезы окрашивали гематоксилином и эозином по стандартным прописям. Общее гистологическое строение и микроструктурные изменения в гистологических препаратах изучали под световым микроскопом.

Гистологическим исследованием были подтверждены и дополнены патологоанатомические диагнозы, установленные после вскрытия трупов погибших животных. Наиболее выраженные повреждения и типичные изменения у всех погибших

Citation:

Lisova, V., Dubinenko, O. (2017). Histological changes in dogs at coronaviral infection. Scientific Messenger LNUVMB, 19(78), $154-157$. 
собак зафиксированы нами в тонком отделе кишечника (в тошей и подвздошной кишках) и регионарных к нему лимфатических узлах, а также в селезенке. Показано, что морфологическими проявлениями коронавирусной инфекиии у погибших собак на микроскопическом уровне являются следуюшие признаки: наличие экссудативного воспаления в тонком отделе кишечника в виде серозно-фибринозного еюно-илеита; гиперплазия одиноких и множественных лимфоидных узелков слизистой оболочки тонкого отдела кишечника; гиперплазия и серозно-геморрагический лимфаденит мезентериальных лимфатических узлов; фокусы геморрагий и геморрагические инфаркты в паренхиме селезенки; гиперплазия лимфоидных узелков селезенки; фокусы геморрагий в серозной оболочке тонкого отдела кишечника; Также неспецифическими, но постоянньми морфологическими признаками, которые возникали вследствие нарушения кровообращения и сердечной недостаточности, были: пассивная венозная гиперемия печени и почек; дистрофические прочессы в паренхиме печени и почек. Таким образом, во время коронавирусной инфекции развиваются местные и обшуие иммунологические процессы. Поэтому дополнительными диагностическими маркерами выступают гиперпластические и воспалительные изменения в регионарных к местам репродукции вируса лимфоидных органах.

Ключевые слова: собаки, коронавирусная инфекция, гистологические изменения, серозно-фибринозный еюно-илеит, геморрагии, гиперплазия, лимфоидные узелки, серозно-геморрагический лимфаденит.

\title{
Histological changes in dogs at coronaviral infection
}

\author{
V. Lisova, O. Dubinenko \\ lisovav@ukr.net
}

\begin{abstract}
National University of life and environmental sciences of Ukraine, Heroyiv Oborony Str., 11, Kyiv, 03041, Ukraine
\end{abstract}

The article presents the results of the study of histological changes in organs and tissues of dogs for coronavirus infection. The histological study of the pathological material of cadavers $(n=5)$ dogs of different breeds and sex between the ages of 2 to 6 months, who died with diarrheal syndrome. The study of presence of coronavirus, without other assiociants, in these cases had previously been confirmed in the polymerase chain reaction analysis of fecal samples. The made histological sections were stained with hematoxylin and eosin according to standard prescriptions. The general histological structure and microstructural changes in histological preparations were studied under a light microscope.

Histological studies have been confirmed and supplemented with pathoanatomical diagnoses, established after autopsies of dead bodies of dead animals. The most pronounced lesions and typical change in all dead dogs fixed contact in the small intestine (jejunum and to the ileum) and the regional lymph nodes to it, as well as in the spleen. It is shown that the morphological manifestations of coronavirus infection in dogs following features are on the microscopic level: the presence of exudative inflammation in the small intestine in the form serous-fibrinous jejuno-ileitis; hyperplasia of single and congested lymphoid nodes of the mucous membrane of the small intestine; hyperplasia and serous-hemorrhagic lymphadenitis mesenteric lymph nodes; foci of hemorrhage and hemorrhagic heart attacks in the spleen parenchyma; hyperplasia lymphoid nodes of the spleen; foci of hemorrhage in the serous membrane of the small intestine. Also, non-specific, but constant morphological features, which arose as a result of circulatory disorders and heart failure were: passive venous congestion of the liver and kidney; degenerative processes in the liver and kidney parenchyma. Consequently, local and general immunological processes develop during the coronaviral infection. Therefore, additional diagnostic markers appear hyperplastic and inflammatory changes of regional seats to the reproduction of the virus lymphoid organs.

Key words: dogs, coronavirus infection, histological changes, serous-fibrinous jejuno-ileitis, hemorrhage, hyperplasia, lymphoid nodes, serous-hemorrhagic lymphadenitis.

\section{Вступ}

Парвовірус собак (CPV) і кишковий коронавірус собак (CECoV) часто називають причиною діареї у собак (Godsall et al., 2010). За даними М.Л. Радзиховського (2016), найрозповсюдженішим ентеровірусом за 2007-2015 роки був парвовірус, 1237 (51,6\%) позитивних проб з 2396 досліджуваних. За 2010-2015 роки корона- та ротавірусний ентерит діагностували у $18,5 \%$ та 23,5\% проб, отриманих від хворих собак (Radzykhovs'kyy, 2016). Хоча кишковий коронавірус собак (CECoV) є менш поширеним, все ще потенційно важливим збудником (Godsall et al., 2010).

У літературному огляді щодо недавньої генетичної еволюції CCoV і появи нових CoVs в собачих, проведеному N. Decaro й C. Buonavoglia (2008), повідомляється, що поява важкого гострого респіраторного синдрому в людини спричинила новий інтерес до коронавірусів тварин (CoVs) як потенційних агентів прямих і непрямих зоонозів (Decaro and Buonavoglia, 2008). Також є повідомлення щодо виділення раніше невідомого коронавірусу в людини з гострою пневмонією та подальшою нирковою недостатністю з фатальним результатом в Саудівській Аравії (Zaki et al., 2012). Клінічна картина була надзвичайно схожою 3 початком вибуху серйозного гострого респіраторного синдрому (ГРВІ) у 2003 році, отже коронавіруси тварин можуть викликати важкі захворювання у людей, наголошує автор. Собачий респіраторний коронавірус $(\mathrm{CRCoV})$ наразі являє собою новий коронавірус собак, який вже поширений в Північній Америці, Японії і ряді європейських країн. Даний вірус за генетичними і антигенними властивостями відрізняється від кишкового собачого коронавіруса, тому для встановлення діагнозу необхідні специфічні тести, повідомляють автори (Erles and Brownlie, 2008).

Також з'явилися повідомлення N. Decaro i співав. (2012) про генетичну i біологічну характеристики нового пантропного собачого коронавіруса (CCoV), штаму 450/07. Після експериментального зараження новим пантропним ізолятом в більшості інфікованих собак спостерігали діарею і гостру лімфопенію. Знач- 
ні пошкодження і гістологічні зміни в основному спостерігали в кишечнику i лімфоїдних тканинах, хоча в деяких тварин виявили також виразні зміни і в паренхіматозних органах (Decaro et al., 2012).

Посилення епідеміологічного нагляду за CoVs призвело до виявлення нових вірусів, генотипів, патотипів і безлічі варіантів у тварин і людини. У собак $\mathrm{CoV}$, пов'язаний 3 м'яким ентеритом, був відомий 3 1970-х років. Але штами $\mathrm{CoV}$ з різними біологічними і генетичними властивостями відносно до класичних штамів CCoV були виявлені в собак протягом останніх кількох років, що призвело до повного перегляду $\mathrm{CoV}$-індукованих захворювань собачих (Decaro and Buonavoglia, 2008).

Отже, збудник еволюціонує, змінюється до змін клініко-морфологічної картини хвороби. Щодо патоморфології даної хвороби, є невелика кількість повідомлень, зокрема в англомовних джерелах (Zappulli et al., 2008; Decaro et al., 2012). Отже, патогенез і патоморфологія хвороби потребують ширшого висвітлення. Тому метою даного етапу дослідження було вивчити гістологічну картину коронавірусної інфекції в собак. Для досягнення мети були поставлені такі завдання: 1) проаналізувати літературні джерела щодо коронавірусної інфекції; 2) провести гістологічне дослідження патматеріалу; 3) визначити гістологічні характеристики хвороби.

\section{Матеріал і методи досліджень}

Робота виконувалась в патогістологічній лабораторії кафедри патологічної анатомії факультету ветеринарної медицини НУБіП України. Матеріалом дослідження слугував патологічний матеріал, відібраний під час патологоанатомічного розтину трупів загиблих 3 діарейним синдромом собак різних порід і статей віком від 2-х до 6-ти місяців $(\mathrm{n}=5)$. Наявність коронавіруса, без інших асоціантів, в загиблих тварин за життя була підтверджена ПЛР при аналізі фекальних зразків. Основним методом, яким користувались в роботі, було гістологічне дослідження, під час якого фіксували й описували мікроструктурні зміни в органах і тканинах. Патологічний матеріал після відбору одразу фіксували в 10\%-ому водному розчині нейтрального формаліну з подальшою заливкою в ущільнююче середовище (парафін). Виготовлені гістологічні зрізи фарбували гематоксиліном Караці й еозином за стандартними прописами (Goralskij et al., 2011). Загальну гістологічну будову і мікроструктурні зміни в гістологічних препаратах вивчали під світловим мікроскопом MC 100LED (Micros Austria) при збільшеннях від 70 до 1000.

\section{Результати та їх обговорення}

При гістологічному дослідженні в усіх випадках були виявлені різного ступеня і характеру зміни в серозній і слизовій оболонках тонкого відділу кишечнику, зокрема в порожній і клубовій кишках, в мезентеріальних лімфатичних вузлах, селезінці, печінці й нирках.
У порожній і клубовій кишках спостерігали ознаки запальної гіперемії судин серозної оболонки і підслизової основи, а також іiі набряк внаслідок серозного просочення. Навколо гіперемійованих судин, переважно серозної оболонки, часто виявляли геморагії. У дистальній частині порожньої кишки спостерігали гіперплазію одиноких і скупчених лімфоїдних вузликів кишкової стінки. Скупчення великої кількості лімфоцитів $з$ численними мітозами, що являють собою лімфоїдні утворення кишкової стінки, набували округлого вигляду та інтенсивно фарбувались гематоксиліном. Надалі гіперпластичні процеси змінювались на некробіотичні. Вогнищеві ураження лімфоїдного апарату кишечнику в переважній більшості випадків комбінувалися з дифузними змінами дифтеритичного типу. Фібринозний ексудат виявлявся при цьому не тільки на поверхні, а й у глибині слизової оболонки, в якій є деструктивні і некробіотичні зміни. Виявлені в порожній і клубовій кишках зміни є морфологічним проявом серозно-фібринозної форми ексудативного запалення. Таким чином, найбільш виразні зміни реєстрували в тонкому відділі кишечнику, що зумовлено насамперед розмноженням тут збудника інфекції. Некроз і втрата епітелію ворсинок тонкого відділу кишечнику та ймовірне порушення секреції келихоподібних клітин призводить до руйнування захисного бар'єру в тонкому відділі кишечнику, що разом 3 порушенням секреції травних залоз (печінки і підшлункової залози) і моторики кишечнику веде до активації умовно-патогенної мікрофлори. Саме про це свідчить помітне погіршення стану тварин за відсутності антибактеріальної терапії. Діарейний синдром як одна з головних клінічних ознак і ключова ланка патогенезу коронавірусної інфекції обумовлений розвитком в даному випадку серозно-фібринозного ентериту, оскільки в ділянках запалення відбувається втрата зрілого епітелію із всмоктуючої поверхні, порушується пристінкове травлення і клітинне всмоктування.

При мікроскопічному дослідженні печінки відмічали розширення і переповнення кров'ю синусоїдних капілярів, особливо в центрі часточок, деструкцію балкової структури печінки i, як наслідок, хаотичне розташування гепатоцитів. Формені елементи крові, переважно еритроцити, в просвітах судин тріад i центральних вен мали вигляд безструктурних еозинофільних мас. Виявляли зернисту дистрофію гепатоцитів, яка морфологічно проявлялася набуханням клітин, зникненням прозорості цитоплазми, появою зернистості білкової природи, що виникає в результаті коагуляції білкових молекул. У окремих випадках виявляли невеликі ділянки жирової дистрофії з утворенням характерних вакуолей різних розмірів у цитоплазмі клітин.

У паренхімі селезінки знаходили множинні фокуси геморагій різних розмірів і поодинокі геморагічні інфаркти. Останні, на відміну від крововиливів, мали досить чіткі контури й характерну трикутну форму. Макроскопічно вираженої зернистої структури органу надавали гіперплазовані внаслідок активної проліферації клітин лімфоїдного ряду лімфоїдні вузлики. 
У регіонарних, а саме мезентеріальних, лімфатичних вузлах також виявляли гіперплазію лімфоїдних вузликів внаслідок активної проліферації клітин лімфоїдного ряду. Також спостерігали ознаки серозногеморагічного запалення у вигляді серозного просочення паренхіми лімфовузлів і виходу формених елементів крові з серозним ексудатом.

У нирках були виявлені, відповідно до описаних раніше макроскопічних змін, морфологічні ознаки пасивної венозної гіперемії і зернистої дистрофії.

Отже, під час коронавірусної інфекції розвиваються місцеві й загальні імунологічні процеси. Тому додатковими діагностичними маркерами виступають гіперпластичні й запальні зміни в регіонарних до місць репродукції віруса лімфоїдних органах - мезентеріальних лімфатичних вузлах, а також лімфоїдних утвореннях слизової оболонки кишечнику.

\section{Висновки}

Гістологічним дослідженням були підтверджені й доповнені патологоанатомічні діагнози, встановлені після розтинів трупів загиблих тварин. За результатами нашого дослідження морфологічні критерії, на яких базується патоморфологічний діагноз за коронавірусної інфекції в собак, включають: 1) серознофібринозний ієюно-ілеїт; 2) гіперплазію одиноких i скупчених лімфоїдних вузликів слизової оболонки тонкого відділу кишечнику; 3) гіперплазію і серозногеморагічний лімфаденіт мезентеріальних лімфовузлів; 4) фокуси геморагій і геморагічні інфаркти в паренхімі селезінки; 5) гіперплазію лімфоїдних вузликів селезінки; 6) фокуси геморагій в серозній оболонці тонкого відділу кишечнику; 7) пасивну венозну гіперемію печінки і нирок; 8) дистрофічні процеси в паренхімі печінки й нирок.

Перспективи подальших досліджень. 3 метою повного вивчення патоморфологічної картини коронавірусного ентериту в собак на наступному етапом доцільно дослідити характеристики даного захворювання з використанням гістохімічних методів дослідження. Також визначити критерії патоморфологічної диференціації від інших, схожих за клінікоморфологічними проявами інфекційних хвороб собак.

\section{Бібліографічні посилання}

Godsall, S.A., Clegg, S.R., Stavisky, J.H. (2010). Epidemiology of canine parvovirus and coronavirus in dogs presented with severe diarrhoea to PDSA. Pet Aid hospitals. Veterinary research. 167, 196-201.

Radzykhovs'kyy, M.L. (2016). Monitorynh enterytiv virusnoyi etiologiyi u sobak [Monitoring enteritis viral etiology in dogs].Scientific Messenger of National University of Veterinary Medicine and Biotechnologies named after S.Z. Gzhytsky. 18, 1(65), 138-142 (in Ukrainian).

Decaro, N., Buonavoglia, C. (2008). An update on canine coronaviruses: viral evolution an d pathobiology. Veterinary Microbiology. 10, 132(34), 221-234.

Zaki, A.M., van Boheemen, S., Bestebroer, T.M., Osterhaus, A.D., Fouchier, R.A. (2012). Isolation of a Novel Coronavirus from a Man with Pneumonia in Saudi Arabia. N Engl J Med. 367, 1814-1820. Available at : http://www.nejm.org/doi/full/10.1056/NEJMoa12117 21

Erles, K., Brownlie, J. (2008). Canine Respiratory Coronavirus: An Emerging Pathogen in the Canine Infectious Respiratory Disease Complex. Veterinary Clinics of North America: Small Animal Practice. 38(4), 815-825.

Decaro, N., Mari, V., von Reitzenstein, M. (2012). A pantropic canine coronavirus genetically related to the prototype isolate $\mathrm{CB} / 05$. Vet Microbiol. 159(1-2), 239-244.

Zappulli, V., Caliari, D., Cavicchioli, L. (2008). Systemic fatal type II coronavirus infection in a dog: Pathological findings and immunohistochemistry. Research in Veterinary Science. 84(2), 278-282.

Goralskij, L.P., Homych, V.T., Kononskij, O.I. (2011). Osnovy histologichnoyi tehniky i morfofunkcionalni metody doslidjen u normi ta pry patologiyi [Foundations of histological engineering and morphofunctional methods of research in norm and pathology]. Jytomir, Ukrainian: Polissya (in Ukrainian).

Received 18.09.2017

Received in revised form 17.10.2017 Accepted 20.10.2017 